\title{
Efficacy of cytisine in helping smokers quit: systematic review and meta-analysis
}

\author{
Peter Hajek, Hayden McRobbie, Katie Myers
}

UK Centre for Tobacco Control Studies, Wolfson Institute of Preventive Medicine, Barts and The London School of Medicine and Dentistry, Queen Mary University of London, London, UK

\section{Correspondence to} Dr Hayden McRobbie, Tobacco Dependence Research Unit, 55 Philpot Street, London, E1 2JH, UK;

h.j.mcrobbie@qmul.ac.uk

Received 22 November 2012 Revised 22 November 2012 Accepted 16 January 2013 Published Online First 12 February 2013

\section{SLinked}

- http://dx.doi.org/10.1136/ thoraxjnl-2013-203246

To cite: Hajek $P$, McRobbie $\mathrm{H}$, Myers $\mathrm{K}$. Thorax 2013;68: 1037-1042.

\section{ABSTRACT}

Background A recent rigorous study has shown that cytisine, a low-cost drug, is effective for smoking cessation. A number of earlier studies exist, mostly from former communist countries where cytisine has been used since the 1960s. The key question now is whether there is sufficient evidence to warrant licensing cytisine or whether more work is needed. A systematic review was undertaken to assess the efficacy of cytisine in smoking cessation.

Methods The Cochrane Library, CINAHL, Embase, Medline and PsycINFO databases were searched for relevant data. Data from controlled trials were entered into two separate meta-analyses. The first considered the strictest definition of outcome and longest follow-up from all available studies and the second pooled outcomes from studies with biochemically validated abstinence and follow-up of 6 months or longer. Results Eight controlled trials were identified. Seven trials provided extractable data and, when pooled (first meta-analysis), produced a risk ratio (RR) of 1.57 (95\% $\mathrm{Cl} 1.42$ to 1.74). Data from two high-quality studies (second meta-analysis) produced a pooled RR of 3.29 (95\% Cl 1.84 to 5.90). Patients on cytisine reported more gastrointestinal symptoms than patients on placebo $(\mathrm{RR}=1.76,95 \% \mathrm{Cl} 1.28$ to 2.42 ). There was no difference in overall reports of adverse events and no specific safety concerns emerged.

Conclusions Cytisine is an effective treatment for smoking cessation with efficacy comparable to that of other currently licensed treatments. Given its low cost and potential for public health benefit, expedited licensing of cytisine for smoking cessation is warranted.

\section{BACKGROUND}

During World War II when the supply of tobacco to the Balkans was interrupted, people took to smoking the leaves of Golden Rain, a shrub endemic there ${ }^{1}$ but also seen in English gardens. The plant, Cytisus laburnum, contains an alkaloid cytisine which is a nicotine analogue, acting as a partial nicotinic acetylcholine receptor agonist. It has a high affinity for the $\alpha-4 \beta-2$ receptor subtype, which is thought to be the main receptor that mediates the central effects of nicotine. ${ }^{2}$

The observation that cytisine satisfies smokers led to the development of cytisine tablets as a treatment for smokers wishing to quit. The tablets have been produced in Bulgaria with the trade name Tabex since $1964 .^{1}$ During the 1970 s Tabex was used in several other Eastern European countries and it remains in use in Bulgaria and Poland. The

\section{Key messages}

What is the key question?

- Cytisine is a plant extract which has been evaluated and used for smoking cessation in former communist countries since the 1960s and inspired the development of varenicline.

\section{What is the bottom line?}

- If effective, cytisine could offer a low-cost treatment alternative that would be important especially in low- and middle-income countries.

\section{Why read on?}

- We present a systematic review and meta-analysis of all existing cytisine studies, consider the drug's safety and present a verdict regarding its efficacy and recommendations concerning its licensing.

tablets were originally produced by Pharmachim and later by Sopharma, another Bulgarian pharmaceutical company (http://www.sopharma.com/ tabex.phtml).

The first randomised placebo controlled trials of Tabex were published in Eastern Europe in the 1970s, long before any smoking cessation medication was available in the West. Due to both language and Iron Curtain barriers, this went unnoticed in the West until Pfizer launched a partial nicotinic receptor agonist varenicline, inspired by and similar to Tabex, as an effective treatment for smoking cessation in $2006 .^{23}$

Two independent systematic reviews examined the early trials of cytisine ${ }^{45}$ and concluded that they provide evidence of efficacy, but that an additional rigorous test using modern methodology is needed.

Since then, two randomised placebo controlled trials of the drug which conform to the strict Russell standard of reporting the results of smoking cessation trials $^{6}$ were completed. ${ }^{7}$ The second of these trials was published in the New England Journal of Medicine and generated interest in the media and among smokers. ${ }^{8}$ The reason for this is that, compared with other smoking cessation treatments, Tabex is inexpensive..$^{5}$ If it is an effective medication, this would have implications for health expenditure and would be a particularly welcome development for smokers in developing countries who cannot afford the current licensed medications. 
This systematic review aims to examine the data currently available on the safety and efficacy of cytisine and to identify any high priority gaps in knowledge.

\section{METHODS}

\section{Literature search}

The following electronic databases were searched: MEDLINE; MEDLINE In-Process and Other Non-Indexed Citations; PsycINFO; AMED; EBM reviews (including Cochrane Methodology Register, Health Technology Assessment, and NHS Economic Evaluation Database), all searched from their earliest records to July 2012.

The search strategy combined cytisine-specific terms (cytisine or cytisius laburnum or tabex) combined with smoking and smoking cessation terms (smoking or tobacco or smoking cessation or quit\$ smok\$ or stop\$ smok\$ or ceas\$ smok\$) (see Appendix 1). Database searches were undertaken by one of the authors (KM) and the references were downloaded into a reference management database (EndNote).

\section{Selection of studies for inclusion}

The process for selecting reviews and trials for this review is shown in figure 1 . The titles and abstracts of papers identified from the literature search were screened by two reviewers (HM and $\mathrm{KM}$ ) to assess their potential relevance to the review. A screening checklist was used and papers that did not primarily address the efficacy of cytisine for smoking cessation were excluded at this stage.

Full papers of potentially relevant studies were obtained. All studies examining the efficacy of cytisine on smoking cessation were included and clustered by design. Only controlled trials were included in the meta-analysis. Translations of the papers written in German and Russian were obtained from http://www.stop-tabac.ch/cytisine/ and checked against the originals by $\mathrm{PH}$. No discrepancies in identifying relevant papers occurred between the reviewers.

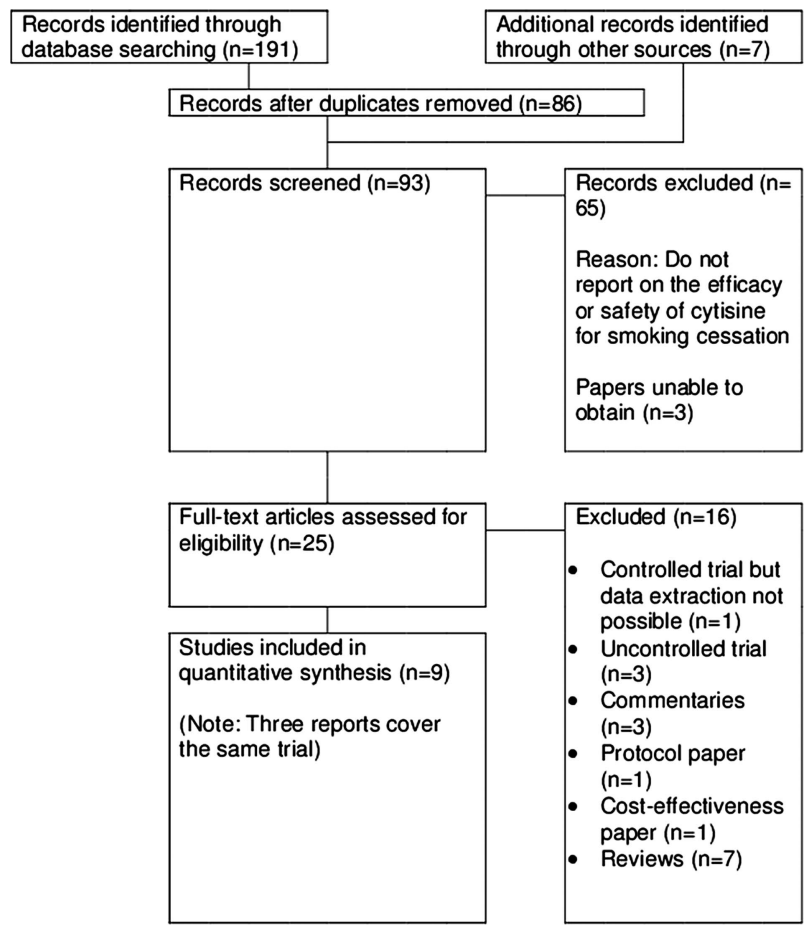

Figure 1 PRISMA flow diagram.
Studies were independently rated by two reviewers (HM and KM) for methodological quality using critical appraisal checklists provided by the National Institute for Health and Clinical Excellence (NICE). ${ }^{9}$ Their conclusions were checked by the third reviewer $(\mathrm{PH})$ who reconciled any differences. For each study, data were extracted on the setting, study period, abstinence rates, whether self-reported abstinence was biochemically validated, study design, other types of interventions administered and adverse events (see table 1).

\section{Statistical evaluation}

Data were extracted using the longest follow-up and the strictest definition of outcome reported. The full sample was included as the denominator with participants whose outcome data were missing classified as treatment failures. Data were entered into the RevMan programme developed for Cochrane meta-analyses. ${ }^{10}$ A pooled risk ratio (RR) was calculated using a fixed effects model. Statistical heterogeneity was assessed using the $\mathrm{I}^{2}$ statistic. Where there was significant heterogeneity, a random effects model was used. ${ }^{11}$ Two meta-analyses of drug efficacy are included. The first uses the strictest outcome measure at the longest follow-up from all seven studies. The second includes data from the two studies with the highest quality rating which validated self-reported abstinence biochemically. We also extracted and analysed data on adverse events.

\section{RESULTS}

Of 93 records identified and screened (after removal of duplicates), 65 were excluded. Twenty-eight papers were screened in full. Nine relevant papers were identified of which seven controlled trials were included in the meta-analysis.

\section{Summary of identified studies \\ Cohort studies}

Four Eastern European papers published between 1967 and 1972 reported outcomes for cohorts of smokers treated with cytisine. ${ }^{12-15}$ Due to absence of controls, these studies provide little relevant information. More recently Zatonski et al followed up 436 smokers who received cytisine and a single session of brief behavioural support. At 1 year, $14 \%$ of the sample achieved carbon monoxide-verified abstinence. ${ }^{16}$

\section{Controlled trials}

In 1968 Paun and Franze conducted an early non-randomised study comparing outcomes in several cohorts of smokers treated with cytisine $(\mathrm{N}=366)$ with a cohort treated with placebo $(\mathrm{N}=239)$ (table 1$)$. At the 8 -week follow-p, cytisine was significantly more effective than placebo. ${ }^{17}$

Scharfenberg et $a l^{18}$ conducted a large randomised doubleblind placebo-controlled trial. The main publication was preceded by two papers covering preliminary results. ${ }^{19} 20$ Follow-up data at 1,6 , and 24 months were collected by post. The response rate at 2 years was $66 \%$. Cytisine $(\mathrm{N}=607)$ was significantly more effective than placebo $(\mathrm{N}=607)$ at all time points.

Schmidt compared 16 different medications with a placebo in what was at the time an epic randomised trial involving 2475 smokers. The study involved no face-to-face contact and relied on posted medications and questionnaires. ${ }^{21}$ Only one kind of 'generic' placebo tablet was used. Cytisine $(\mathrm{N}=250)$ surpassed placebo $(\mathrm{N}=270)$ at the end of treatment (4 weeks) but the difference was not significant at the 3-month follow-up.

Marakulin et al allocated smokers to autogenic training (a relaxation method) alone $(\mathrm{N}=232)$ or combined with cytisine 
Table 1 Summary of controlled trials of cytisine for smoking cessation

\begin{tabular}{|c|c|c|c|c|c|c|}
\hline First author & Study design and quality* & Study population & Behavioural support & $\begin{array}{l}\text { Length of } \\
\text { follow-up }\end{array}$ & Main results & Confounders/ comments \\
\hline Paun (1968) & $\begin{array}{l}\text { Placebo-controlled } \\
\text { trial (-) }\end{array}$ & $\begin{array}{l}\text { Cytisine: } \mathrm{N}=366 \\
\text { Placebo: } \mathrm{N}=239\end{array}$ & Unclear & 8 weeks & $\begin{array}{l}\text { Cytisine: } 55 \%(n=202) \\
\text { Placebo: } 33 \%(n=80) \\
(p<0.001)\end{array}$ & $\begin{array}{l}\text { No validation of abstinence } \\
\text { Non-randomised, results of } 2 \text { sites using drug } \\
\text { compared with 3rd site using placebo }\end{array}$ \\
\hline $\begin{array}{l}\text { Scharfenberg (1971), } \\
\text { Benndorf (1968), Benndorf } \\
1968\end{array}$ & $\begin{array}{l}\text { Randomised placebo-controlled } \\
\text { trial }(+)\end{array}$ & $\begin{array}{l}\text { Exclusions: hypertension, } \\
\text { arteriosclerosis } \\
\text { Cytisine: } \mathrm{N}=607 \\
\text { Placebo: } \mathrm{N}=607\end{array}$ & $\begin{array}{l}\text { Initial session and follow-up } \\
4-6 \text { weeks after starting } \\
\text { treatment }\end{array}$ & $\begin{array}{l}4 \text { weeks } \\
6 \text { months } \\
2 \text { years }\end{array}$ & $\begin{array}{l}\text { Cytisine: } 65 \%(n=395) \\
\text { Placebo: } 41 \%(n=246) \\
\text { ( } p<0.001) \\
\text { Cytisine: } 30 \%(n=185) \\
\text { Placebo: } 16 \%(n=97) \\
\text { ( } p<0.001) \\
\text { Cytisine: } 21 \%(n=127) \\
\text { Placebo: } 13 \%(n=79) \\
\text { ( } p<0.001)\end{array}$ & $\begin{array}{l}\text { No validation of abstinence } \\
\text { Two-year follow-up by mail with } 66 \% \\
\text { response rate }\end{array}$ \\
\hline Schmidt (1974) & $\begin{array}{l}\text { Randomised placebo-controlled } \\
\text { trial }(+)\end{array}$ & $\begin{array}{l}\mathrm{N}=2470 \text { smokers } \\
\text { recruited via TV and } \\
\text { newspaper ads } \\
\text { Cytisine: } \mathrm{N}=250 \\
\text { Placebo: } \mathrm{N}=270\end{array}$ & Single information lecture & $\begin{array}{l}4 \text { weeks } \\
3 \text { months }\end{array}$ & $\begin{array}{l}\text { Cytisine: } 41 \%(n=103) \\
\text { Placebo: } 31 \%(n=84) \\
\text { (p<0.05) } \\
\text { Cytisine: } 25 \%(n=68) \\
\text { Placebo: } 21 \%(n=57) \\
\text { (NS) }\end{array}$ & $\begin{array}{l}\text { No validation of abstinence } \\
\text { All contacts by post, } 74 \% \text { response rate at } \\
3 \text { months }\end{array}$ \\
\hline Marakulin (1984) & Controlled trial (-) & $\begin{array}{l}\text { Autogenic training (AT): } \\
\mathrm{N}=232 \\
\text { Autogenic training + } \\
\text { cytisine: } \mathrm{N}=388\end{array}$ & $\begin{array}{l}\text { Inpatient autogenic training } \\
\text { treatment }\end{array}$ & 3 weeks & $\begin{array}{l}\text { AT alone: } 53 \%(n=123) \\
\text { AT+cystisine: } 70.1 \% \\
(n=272) \\
(p<0.5)\end{array}$ & $\begin{array}{l}\text { No validation of abstinence } \\
\text { Unclear allocation to groups } \\
\text { No placebo }\end{array}$ \\
\hline Monova (2004) & $\begin{array}{l}\text { Randomised placebo-controlled } \\
\text { trial (-) }\end{array}$ & $\begin{array}{l}\text { Cytisine: } \mathrm{N}=75 \\
\text { Placebo: } \mathrm{N}=75\end{array}$ & $\begin{array}{l}8 \text { visits over } 60 \text { days to review } \\
\text { smoking diary and for } \\
\text { laboratory tests }\end{array}$ & 26 days & $\begin{array}{l}\text { Cytisine: } 37 \%(n=28) \\
\text { Placebo: } 3 \%(n=2) \\
(p<0.5)\end{array}$ & $\begin{array}{l}\text { Unclear whether double blind } \\
\text { Collected urinary cotinine but unclear if used }\end{array}$ \\
\hline Vinnikov (2008) & $\begin{array}{l}\text { Randomised placebo-controlled } \\
\text { trial }(++)\end{array}$ & $\begin{array}{l}\text { Exclusions: Serious or } \\
\text { unstable medical conditions } \\
\text { Cytisine: } N=85 \\
\text { Placebo: } N=86\end{array}$ & $\begin{array}{l}\text { ' } 2 \text { weeks screening and } \\
\text { counselling' } \\
\text { followed by medication use }\end{array}$ & $\begin{array}{l}8 \text { weeks } \\
6 \text { months }\end{array}$ & $\begin{array}{l}\text { Cytisine: } 10.6 \%(n=9) \\
\text { Placebo: } 5.8 \%(n=5) \\
\text { p=0.36 } \\
\text { Cytisine: } 10.6 \%(n=9) \\
\text { Placebo: } 1.2 \%(n=1) \\
p=0.01\end{array}$ & Russell Standard outcome CO validated \\
\hline West (2011) & $\begin{array}{l}\text { Randomised placebo-controlled trial } \\
(++)\end{array}$ & $\begin{array}{l}\text { Exclusions: Current psychiatric } \\
\text { disorder } \\
\text { Cytisine: } \mathrm{N}=370 \\
\text { Placebo: } \mathrm{N}=370\end{array}$ & $\begin{array}{l}\text { Baseline visit, telephone calls } \\
\text { on } \\
\text { quit date and } 1 \text { week, a } \\
\text { visit at } 4 \text { weeks }\end{array}$ & $\begin{array}{l}6 \text { month } \\
12 \text { months }\end{array}$ & $\begin{array}{l}\text { Cytisine: } 10.0 \%(n=37) \\
\text { Placebo: } 3.5 \%(n=13) \\
\text { p<0.001 } \\
\text { Cytisine: } 8.4 \%(n=31) \\
\text { Placebo: } 2.4 \%(n=9) \\
p<0.001\end{array}$ & Russell Standard outcome CO validated \\
\hline
\end{tabular}

*Quality ratings take into account study design and features highlighted in the column confounders/comments. 


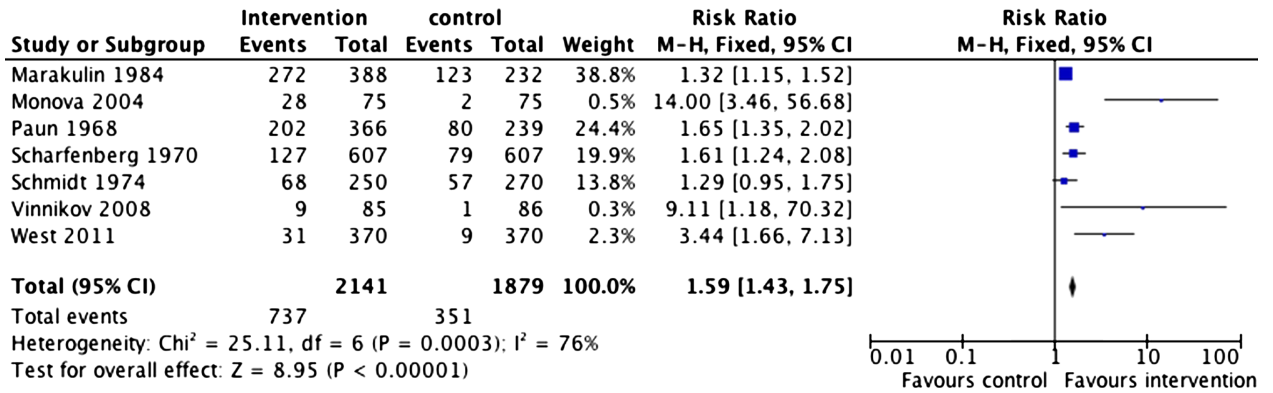

Figure 2 Abstinence rates at longest follow-up from all studies. Access the article online to view this figure in colour.

$(\mathrm{N}=388) .^{22}$ The brief report includes few details and it is not clear if the allocation was random. Quit rates at 3 weeks were significantly higher in the cytisine group.

Vinnikov et $\mathrm{al}^{7}$ randomised smokers to cytisine $(\mathrm{N}=85)$ or placebo $(\mathrm{N}=86)$ with no support other than providing the medication at baseline. The trial was double-blind and it reported validated continuous abstinence rates. The difference between cytisine and placebo at 2 months was large, but it did not reach statistical significance. The difference was significant at 6 months.

West et al randomised smokers to cytisine $(\mathrm{N}=370)$ or placebo $(\mathrm{N}=370)$ in another methodologically strict study. Only brief support was provided, with sessions at days 0 and 28 and a telephone call and an optional support session in between. Follow-up took place at 6 months and 12 months. Cytisine was significantly more effective than placebo at both time points. ${ }^{8}$

A trial by Monova et al is described in a review of evidence produced by the manufacturers of Tabex, ${ }^{23}$ but it remains unpublished. At 4-week follow-up, cytisine was significantly more effective than placebo (Monova et al, unpublished report TAB-SPH-04014: Sopharma plc, 2004).

We found one other controlled trial that did not report any extractable data and so is not included in the main meta-analysis. ${ }^{24}$ The author allocated 62 smokers to anabasine, cytisine (buccal film rather than tablets) or their combination. At 15 days, cytisine and the cytisine/anabasine combination were more effective than anabasine alone.

\section{Meta-analyses}

Figure 2 shows the results of the meta-analysis using all available data. Cytisine was significantly more effective than the comparators $(\mathrm{RR}=1.59$; $95 \% \mathrm{CI} 1.43$ to 1.75$)$. The results are heterogeneous, but this is not because some studies produced negative results but because two trials produced unusually positive findings.

Figure 3 shows the results of the meta-analysis using data from the two new trials with the highest quality ratings, which validated smoking status and provided follow-up for at least 6 months. Cytisine was significantly more effective than placebo, increasing the chance of successful quitting more than threefold $(\mathrm{RR}=3.29 ; 95 \% \mathrm{CI} 1.84$ to 5.90$)$. The results are homogenous.

\section{Cytisine safety}

Five of the seven included studies (including the unpublished report by Monova et al) provide data on adverse events. 782125 Serious adverse events (SAEs) were reported in three studies. The 1974 paper by Schmidt reported 1\% SAEs among participants receiving placebo and 3\% among those receiving cytisine. SAEs included vomiting, stomach pain, renal pain, biliary colic and vision disorders. However, this list includes SAEs from 17 active medications and it is not clear which concern cytisine. One of the modern trials (Monova et al, unpublished, 2004) reports one adverse event (rhabdomyolysis) in the cytisine group and none in the placebo group. The best reported study to date ${ }^{8}$ identified four SAEs in participants on cytisine (lung cancer, cardiac arrest, stroke and tracheal cancer) and three in those on placebo (lung cancer, stroke, chronic obstructive pulmonary disease). The authors note that most SAEs occurred after the end of treatment and concerned pre-existing illness. Across the studies, there were two deaths among the cytisine participants and three among the placebo group.

The most frequently reported adverse event across the studies was gastrointestinal symptoms, which occurred with a greater frequency in the cytisine group than in the placebo group $(12 \%$ vs $7.2 \%$; figure 4). There were no significant differences between cytisine and placebo in SAEs, headache, insomnia or nausea. There was also no difference in the overall incidence of all adverse events (figure 5).

\section{Compliance with cytisine dosing}

The drug dosing for cytisine was established in the 1960s, but the rationale for the dosing schedule is unclear. Patients are asked to take six $1.5 \mathrm{mg}$ tablets, one every $2 \mathrm{~h}$, over the first 3 days and to stop smoking by day 3 . This is followed by five tablets daily for days 4-12 (one tablet every $2.5 \mathrm{~h}$ ), four tablets for days 13-16 (every $3 \mathrm{~h}$ ), three tablets for days 17-20 (every $4 \mathrm{~h}$ ) and two tablets for days 21-25 (every $6 \mathrm{~h}$ ), totalling 100 tablets. Two studies reported on adherence to treatment, both of which showed that patients used fewer tablets than

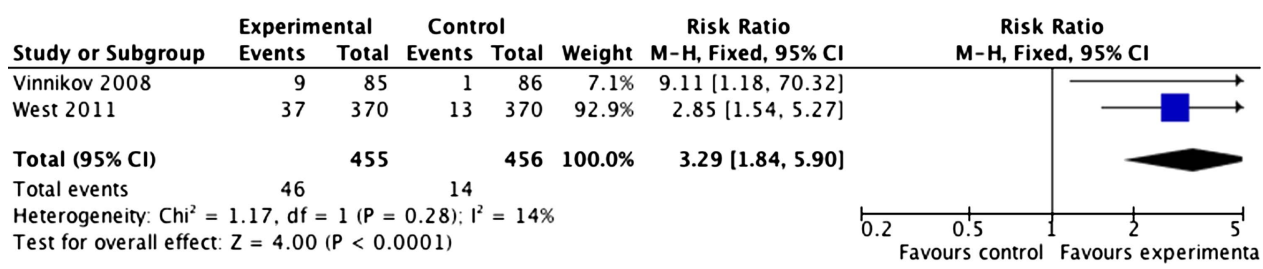

Figure 3 Abstinence rates at 6 months or longer in the two high-quality studies which validated abstinence. Access the article online to view this figure in colour. 


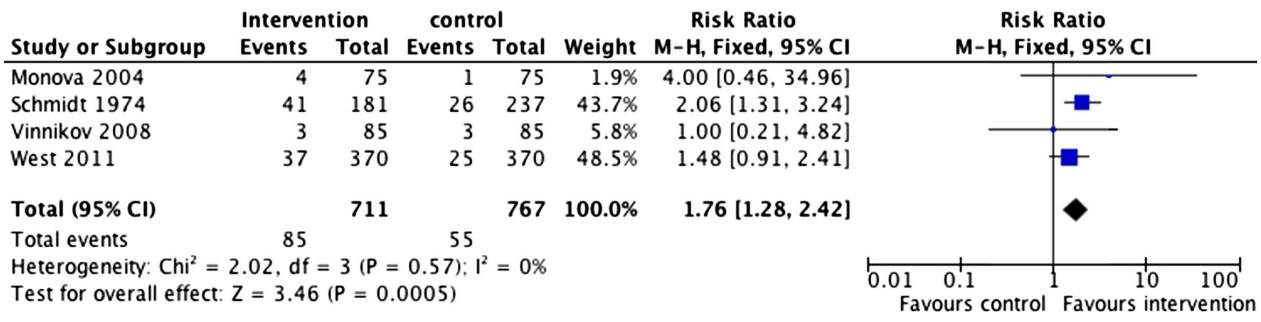

Figure 4 Gastrointestinal symptoms. Access the article online to view this figure in colour.

recommended. ${ }^{17} 25$ In one of the studies, among participants abstinent at the end of treatment, $18 \%$ used more than 50 tablets, $66 \%$ used 21-50 tablets and 16\% used fewer than 20 tablets. The other study found that $50 \%$ of abstainers used $75-$ 100 tablets with the rest using $<75$ tablets.

\section{DISCUSSION}

Further trials-for example, with specific subpopulationswould strengthen the evidence base, but the existing data provide good evidence that cytisine is an effective smoking cessation treatment. The RR of its effect compared with placebo $(1.57-3.29)$ is at least as good as that of other proven treatments currently available. Cochrane meta-analyses report the RRs for nicotine replacement, bupropion and varenicline as $1.58(95 \%$ CI 1.50 to 1.66$), 1.69$ (95\% CI 1.53 to 1.85$)$ and 2.27 (95\% CI 2.02 to 2.55 ), respectively. ${ }^{26-28}$

The overall success rates achieved with cytisine are not higher than those reported for the other medications, but most trials used cytisine with only minimal support. Some distributed the drug by post, and most included only one or two support sessions. In contrast, most trials of varenicline included 20 or more contacts. $^{28} 29$ More intensive support increases long-term success rates. ${ }^{30}$ The synergy between behavioural support and the effects of medication may be even stronger with cytisine than with the other treatments because cytisine in its current form includes a complex dosing schedule. The drug is underused to an extent similar to that seen with oral nicotine replacement. ${ }^{31}$ More frequent contacts during the first few weeks of treatment may improve treatment adherence and increase the chance that patients benefit from the medication.

Summarising the results of drug trials faces a risk of publication bias-that is, negative results are not published. ${ }^{32}$ The risk is reduced in this case by the fact that the drug manufacturer funded only one of the nine trials, but possible under-reporting of negative results cannot be ruled out in any meta-analysis.

No serious concerns about drug safety were raised in any of the existing studies. Side effects were rare and mild. Cytisine caused more gastrointestinal problems than placebo, but there was no difference in overall adverse events. The study population was not very large (2141 smokers treated with cytisine and 1879 in control conditions), but there is additional reassurance in the fact that the tablets have been used in some countries for over 50 years with no safety concerns emerging. The discontinuation rate due to side effects in the recent randomised controlled trial was $6.2 \%$ in the cytisine arm and $4.6 \%$ in the placebo arm $(\mathrm{RR}=1.3 ; 95 \% \mathrm{CI} 0.7$ to 2.5$){ }^{8}$ This is comparable to discontinuation rates observed with other current mediations; for example, Jorenby et al reported 10.5\%, 12.6\% and 7.3\% of participants discontinued treatment with varenicline, bupropion and placebo, respectively, due to adverse events. ${ }^{29}$

Cytisine can be poisonous, but only in very high doses. Children sometimes suck on appealing looking (and apparently pleasant tasting) laburnum seeds or eat them and fall sick, but no fatality has been recorded from such incidents. ${ }^{33}$ It seems virtually impossible to get poisoned with Tabex. A pharmaceutical specialist tried to commit suicide using Tabex tablets twice. She consumed some 50 tablets at the first unsuccessful attempt and increased the dose to 90 tablets on the second, but survived again. $^{14}$

The key question now is whether the current regulatory framework would allow cytisine to be marketed on the basis of the available data. Cytisine is an unusual case in that it did not go through the standard drug development processes. The regulatory authorities may decide to request preclinical trials as few such data exist, and to wait for further trials of the drug's safety and efficacy. This would delay the introduction of a useful medication, but it would have other consequences as well. Should a manufacturer labour through such hurdles and provide the evidence requested, the drug would not be inexpensive any more. The full course of Tabex is currently around US $\$ 36$ online (http://www.buytabexonline.com) compared with approximately US\$152 for an 8-week course of $21 \mathrm{mg}$ nicotine patches and US\$128-536 (depending on the level of coverage) for a 12-week course of varenicline (http://www.pfizerpro.com/hcp/ chantix/cost-formulation).

Regarding questions which await answers, it is possible that the current complex and 'front-loaded' dosing schedule is suboptimal. The efficacy of the medication may increase further with more user-friendly dosing leading to better patient adherence to treatment. It is also possible that the efficacy of the drug would be enhanced with longer pre-quit and post-quit use as is done with varenicline, and with the dose maintained at a higher level during the first few weeks of abstinence from smoking when relapse is common. ${ }^{34}$ There are precedents for

\begin{tabular}{|c|c|c|c|c|c|c|c|}
\hline Study or Subgroup & \multicolumn{2}{|c|}{ Intervention } & \multicolumn{2}{|c|}{ control } & Weight & $\begin{array}{c}\text { Risk Ratio } \\
\text { M-H, Fixed, } 95 \% \mathrm{Cl} \\
\end{array}$ & $\begin{array}{c}\text { Risk Ratio } \\
\text { M-H, Fixed, } 95 \% \mathrm{CI}\end{array}$ \\
\hline Manova 2004 & 12 & 75 & 8 & 75 & $3.1 \%$ & $1.50[0.65,3.46]$ & \\
\hline Scharfenberg 1970 & 113 & 607 & 98 & 607 & $38.3 \%$ & $1.15[0.90,1.47]$ & \\
\hline Schmidt 1974 & 65 & 181 & 99 & 237 & $33.5 \%$ & $0.86[0.67,1.10]$ & \\
\hline Vinnikov 2008 & 4 & 85 & 5 & 85 & $2.0 \%$ & $0.80[0.22,2.88]$ & \\
\hline West 2011 & 76 & 370 & 59 & 370 & $23.1 \%$ & $1.29[0.95,1.75]$ & $=$ \\
\hline Total $(95 \% \mathrm{CI})$ & & 1318 & & 1374 & $100.0 \%$ & $1.09[0.94,1.26]$ & 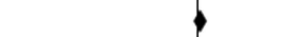 \\
\hline Total events & 270 & & 269 & & & & \\
\hline $\begin{array}{l}\text { Heterogeneity: } \mathrm{Chi}^{2}= \\
\text { Test for overall effect }\end{array}$ & $\begin{array}{l}5.69, \mathrm{df} \\
Z=1.13\end{array}$ & $\begin{array}{l}=4(P= \\
(P=0 .\end{array}$ & $\begin{array}{l}=0.22) ; 1 \\
26)\end{array}$ & $2^{2}=30$ & & & $\begin{array}{lll}0.01 & 0.1 & 1\end{array}$ \\
\hline
\end{tabular}

Figure 5 All adverse events. Access the article online to view this figure in colour. 
higher dosing-for example, the drug has been tested for antidepressant effects in doses up to $22.5 \mathrm{mg}$ /day compared with 3$9 \mathrm{mg} /$ day used for smoking cessation. ${ }^{1}$

The exact mechanism of the effect of cytisine has not been examined to date. It is likely to have effects similar to varenicline-that is, to reduce the enjoyment of smoking during the

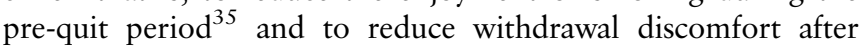
quitting. ${ }^{36}$ Future studies should test these hypotheses. If cytisine does have both of these effects, it would strengthen the case for extending the period of use prior to quitting when reduced reward from smoking may facilitate later abstinence, and for extending its post-quit use to reduce withdrawal discomfort. None of these considerations, however, needs to prevent the use of the medication as it currently exists.

In summary, there is now good evidence that cytisine is an effective treatment for smoking cessation. Given its low cost and potential for large-scale public health benefit, we believe that expedited licensing of cytisine for smoking cessation is warranted.

Acknowledgements We are grateful to the Cochrane Collaboration Tobacco Addiction Group for allowing us access to the unpublished paper by Monova et al.

Contributors All authors made substantial contributions to the conception and design or acquisition of data, analysis and interpretation of data; drafting the article or revising it critically for important intellectual content; and final approval of this version of the manuscript.

Competing interests $\mathrm{PH}$ and HM have provided consultancy for and received research funding from manufacturers of smoking cessation medications. HM is involved in a trial of Tabex funded by the Health Research Council of New Zealand, for which Tabex was provided by the manufacturer.

Provenance and peer review Not commissioned; externally peer reviewed.

\section{REFERENCES}

1 Tutka P, Zatonski W. Cytisine for the treatment of nicotine addiction: from a molecule to therapeutic efficacy. Pharmacol Rep 2006;58:777-98.

2 Coe JW, Vetelino MG, Bashore CG, et al. In pursuit of alpha4beta2 nicotinic receptor partial agonists for smoking cessation: carbon analogs of (-)-cytisine. Bioorg Med Chem Lett 2005;15:2974-9.

3 Kolotkin RL, Crosby RD. Psychometric evaluation of the impact of weight on quality of life-lite questionnaire (IWQOL-lite) in a community sample. Qual Life Res 2002;11:157-71.

4 McRobbie H, Hajek P, Bullen C, et al. Rapid review of non-NHS treatments for smoking cessation. London: National Institute of Health and Clinical Excellence, 2006.

5 Etter J-F. Cytisine for smoking cessation: a literature review and a meta-analysis. Arch Intern Med 2006;166:1553-9.

6 West R, Hajek P, Stead L, et al. Outcome criteria in smoking cessation trials: proposal for a common standard. Addiction 2005:100:299-303.

7 Vinnikov D, Brimkulov N, Burjubaeva A. A double-blind, randomised, placebo-controlled trial of cytisine for smoking cessation in medium-dependent workers. J Smoking Cessation 2008;3:57-62.

8 West R, Zatonski W, Cedzynska $M$, et al. Placebo-controlled trial of cytisine for smoking cessation. N Engl J Med 2011;365:1193-200.

9 National Institute for Health and Clinical Excellence (NICE). Methods for the development of NICE public health quidance. 2nd edn. London: NICE, 2009

10 Review Manager (RevMan) (program). Copenhagen: The Nordic Cochrane Centre, The Cochrane Collaboration, 2008.

11 Higgins J, Green S. Cochrane Handbook for Systematic Reviews of Interventions. Version 5.0.2 (updated September 2009). The Cochrane Collaboration, 2008.

12 Bacvarov VI. Medicinal breaking of the smoking habit. (Remarks to G. Scharfenberg, E. Winkelvosss and S. Benndorf. Munchen Med Wochr 1967;109:1687-9.) Munchen Med Wochr 1967;109:2663-5.

13 Paun D, Franze J. Tabex - registering and treatment of smokers with chronic bronchitis in the consultation against tobacco-smoking - Berlin. Medico-biologic Info 1970;3:15-9.
14 Stoyanov S, Yanachkova M. On the therapeutic effectiveness and tolerance of Tabex. Savremenna Med 1972;23:2088-91.

15 Maliszewski L, Straczynski A. Therapeutic use of Tabex. Wiad Lek 1972;25:2207-10.

16 Zatonski W, Cedzynska M, Tutka P, et al. An uncontrolled trial of cytisine (Tabex) for smoking cessation. Tob Control 2006;15:481-4.

17 Paun D, Franze J. Breaking the smoking habit using cytisin containing "Tabex" tablets. Dtsch Gesundheitsw 1968;23:2088-91.

18 Scharfenberg G, Benndorf S, Kempe G. Cytisine (Tabex) as a pharmaceutical aid in stopping smoking. Dtsch Gesundheitsw 1971;26:463-5.

19 Benndorf S, Kempe G, Scharfenberg G, et al. (Results of smoking cessation treatment with cytisin (Tabex)) (German). Dtsch Gesundheitsw 1968;23:2092-6.

20 Benndorf S, Scharfenberg G, Kempe G, et al. Smoking withdrawal treatment with cytisin (Tabex). Results of a semi-annual survey of former smokers after 4 weeks of therapy. Dtsch Gesundheitsw 1970;24:774-6.

21 Schmidt F. Medikamentose Unterstutzung der Raucherentwohnung: Bericht uber Versuche an uber 500 Rauchern im Doppelblindversuch. MMW Munch Med Wochenschr 1974;116:557-64.

22 Marakulin VS, Komarov VM, Chuprin VV. Treatment of nicotinism. Voen Med Zh 1984:55-8.

23 Dobreva D, Danchev N. Tabex - Sopharma - natural alternative for smoking cessation and treatment of nicotine dependence. Pharmacia 2005:52:30-5.

24 Ostrovskaia TP. Results of clinical investigation of anti-nicotine drug patches (in Russian). Med Tekh 1994;(3):42-3.

25 Scharfenberg G, Benndorf S, Kempe G. Cytisine (Tabex) as a pharmaceutical aid in stopping smoking. Dtsch Gesundheitsw 1971;26:463-5.

26 Stead LF, Perera R, Bullen C, et al. Nicotine replacement therapy for smoking cessation. Cochrane Database Syst Rev 2008;(1):CD000146.

27 Hughes JR, Stead LF, Lancaster T. Antidepressants for smoking cessation. Cochrane Database Syst Rev 2007;(1):CD000031.

28 Cahill K, Stead LF, Lancaster T. Nicotine receptor partial agonists for smoking cessation. Cochrane Database Syst Rev 2012;(4).

29 Jorenby DE, Hays JT, Rigotti NA, et al. Efficacy of varenicline, an alpha4beta2 nicotinic acetylcholine receptor partial agonist, vs placebo or sustained-release bupropion for smoking cessation: a randomized controlled trial. JAMA 2006;296:56-63.

30 US Department of Health and Human Services (USDHHS). Treating tobacco use and dependence: 2008 update. Rockville, MD: USDHHS, Agency for Healthcare Research Quality, 2008

31 Shiffman S, Rolf CN, Hellebusch SJ, et al. Real-world efficacy of prescription and over-the-counter nicotine replacement therapy. Addiction 2002;97:505-16.

32 Godlee F. Clinical trial data for all drugs in current use. BMJ 2012:345:e7304.

33 Richards $\mathrm{HG}$, Stephens A. A fatal case of laburnum seed poisoning. Med Sci Law 1970;10:260-6.

34 Hughes JR, Keely J, Naud S. Shape of the relapse curve and long-term abstinence among untreated smokers. Addiction 2004;99:29-38.

35 Hajek P, McRobbie HJ, Myers KE, et al. Use of varenicline for 4 weeks before quitting smoking: decrease in ad lib smoking and increase in smoking cessation rates. Arch Intern Med 2011;171:770-7.

36 Pisinger $C$, Jorgensen $\mathrm{MM}$, Moller NE, et al. A cluster randomized trial in general practice with referral to a group-based or an Internet-based smoking cessation programme. J Public Health (Oxf) 2010;32:62-70.

\section{APPENDIX 1: SEARCH STRATEGY}

1. cytisine.mp. [ti, ab] $=1446$

2. cytisus laburnum.mp. [ti, ab] $=18$

3. tabex.mp. [ti, ab] $=38$

4. 1 or 2 or $3=1473$

5. smoking.mp. [ti, ab] $=396838$

6. smoking cessation.mp. [ti, ab] $=58005$

7. tobacco.mp. [ti, ab] $=178089$

8. quit $\$$ smok\$.mp. [ti, ab] $=11478$

9. stop\$ smok\$.mp. [ti, ab] $=8564$

10. 5 or 6 or 7 or 8 or $9=476789$

11. 4 and $10=191$ 